\title{
2007 Nissan Altima-7982 Hybrid Electric Vehicle Battery Test Results
}

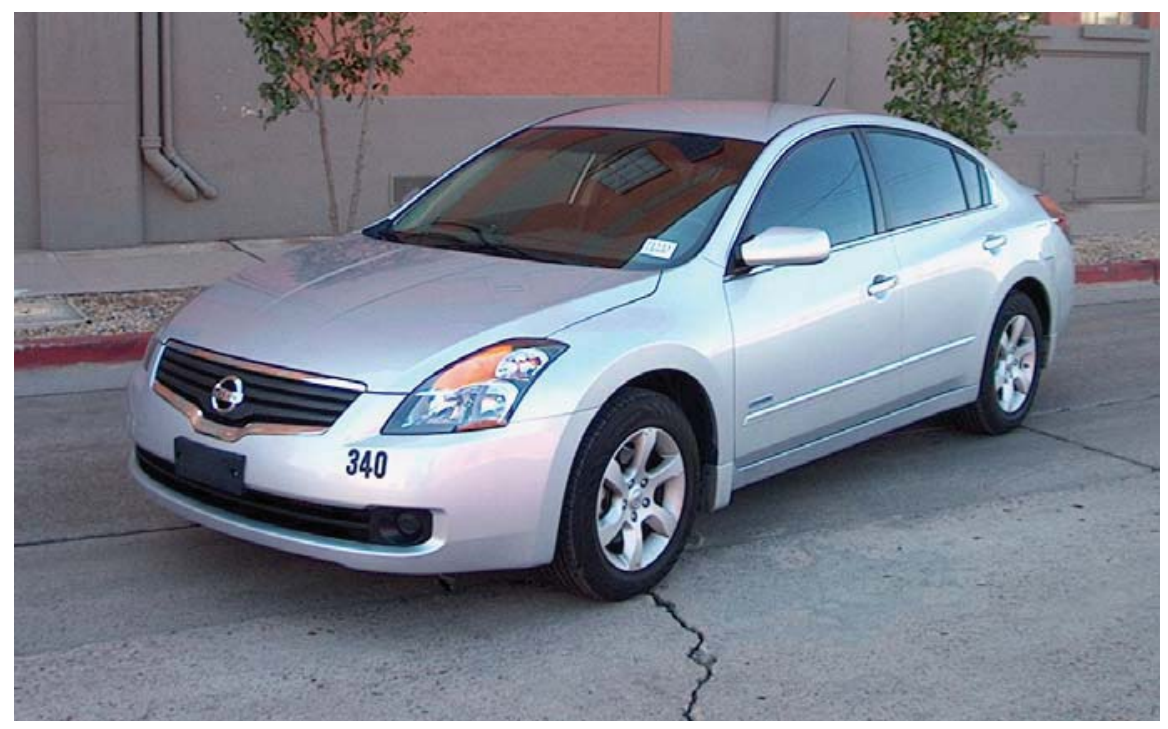

Tyler Gray

Chester Motloch

James Francfort

January 2010

The Idaho National Laboratory is a U.S. Department of Energy National Laboratory Operated by Battelle Energy Alliance 


\title{
2007 Nissan Altima-7982 Hybrid Electric Vehicle Battery Test Results
}

\author{
Tyler Gray ${ }^{1}$ \\ Chester Motloch ${ }^{1}$ \\ James Francfort ${ }^{2}$
}

January 2010

Prepared for the

U.S. Department of Energy

Assistant Secretary for Energy Efficiency and Renewable Energy

Under DOE Idaho Operations Office

Contract DE-AC07-05ID14517

1 Electric Transportation Engineering Corporation

2 Idaho National Laboratory 


\section{Disclaimers}

This document highlights work sponsored by agencies of the U.S. Government. Neither the U.S. Government nor any agency thereof, nor any of its employees, makes any warranty, express or implied, or assumes any legal liability or responsibility for the accuracy, completeness, or usefulness of any information, apparatus, product, or process disclosed, or represents that its use would not infringe privately owned rights. Reference herein to any specific commercial product, process, or service by trade name, trademark, manufacturer, or otherwise does not necessarily constitute or imply its endorsement, recommendation, or favoring by the U.S. Government or any agency thereof. The views and opinions of authors expressed herein do not necessarily state or reflect those of the U.S. Government or any agency thereof. 


\begin{abstract}
The U.S. Department of Energy's Advanced Vehicle Testing Activity conducts several different types of tests on hybrid electric vehicles (HEVs), including testing the HEV batteries when both the vehicles and batteries are new and at the conclusion of 160,000 miles of on-road accelerated testing. This report documents the battery testing performed and battery testing results for the 2007 Nissan Altima HEV, number 7982 (VIN 1N4CL21E27C177982). The battery testing was performed by the Electric Transportation Engineering Corporation. The Idaho National Laboratory and the Electric Transportation Engineering Corporation conduct the Advanced Vehicle Testing Activity for the U.S. Department of Energy's Vehicle Technologies Program.
\end{abstract}




\section{CONTENTS}

ABSTRACT

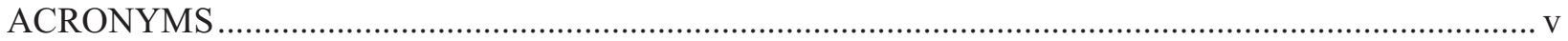

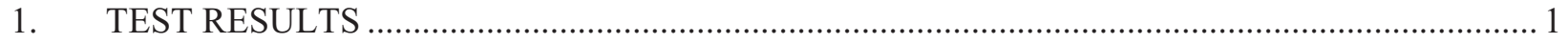

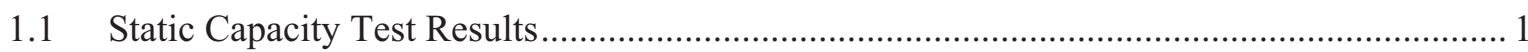

1.2 Hybrid Pulse Power Characterization Test Results............................................................ 2

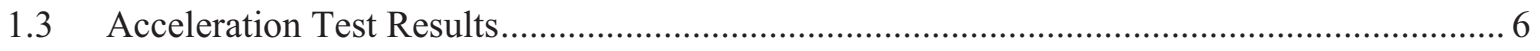

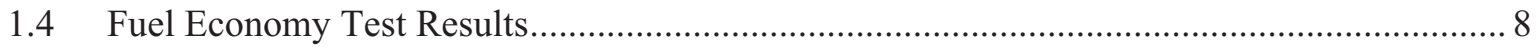

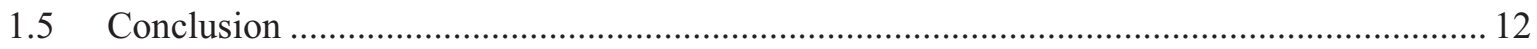

\section{FIGURES}

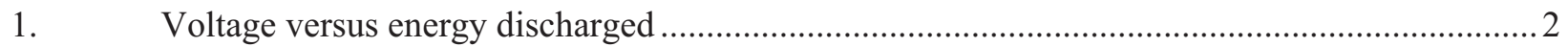

2. Ten-second charge pulse resistance versus energy discharged ............................................. 3

3. Ten-second charge pulse power versus energy discharged …................................................ 3

4. Ten-second discharge pulse resistance versus energy discharged .......................................... 4

5. Ten-second discharge pulse power versus energy discharged ............................................. 4

6. Peak power values with Department of Energy target …................................................... 5

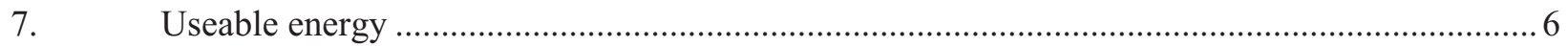

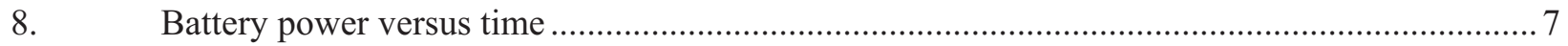

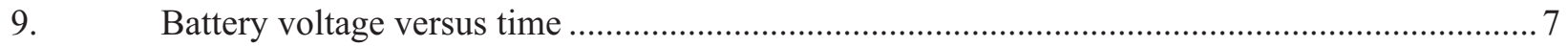

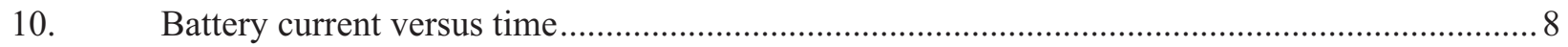

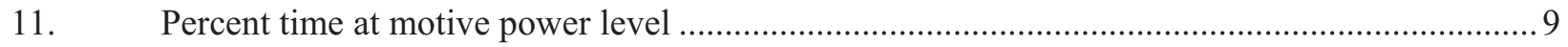

12. Percent time at regenerative power level......................................................................... 10

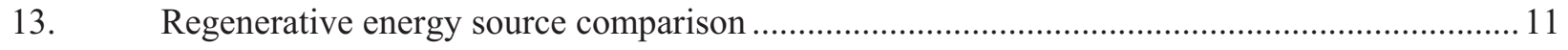

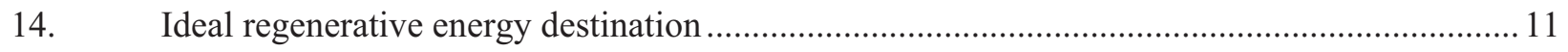

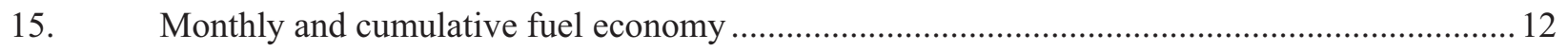




\section{ACRONYMS}

$\begin{array}{ll}\text { Ah } & \text { amp-hour } \\ \text { BOT } & \text { beginning of test } \\ \text { DOE } & \text { U.S. Department of Energy } \\ \text { EOT } & \text { end of test } \\ \text { HEV } & \text { hybrid electric vehicle } \\ \text { HPPC } & \text { Hybrid Pulse Power Characterization } \\ \text { kW } & \text { kilowatt } \\ \text { SOC } & \text { state of charge } \\ \text { V } & \text { volt } \\ \text { VDC } & \text { volt direct current } \\ \text { VIN } & \text { vehicle identification number } \\ \text { Vpc } & \text { volt per cell } \\ \text { Wh } & \text { watt-hour }\end{array}$




\section{Nissan Altima-7982 Hybrid Battery Test Results}

\section{TEST RESULTS}

The U.S. Department of Energy's (DOE's) Advanced Vehicle Testing Activity conducts vehicle, battery, and infrastructure testing on several different vehicle technologies, including hybrid electric vehicles (HEVs). This report provides test results for beginning-of-test (BOT) and end-of-test (EOT) battery testing conducted on a 2007 Nissan Altima HEV, number 7982 (VIN 1N4CL21E27C177982) in the battery test laboratory and during vehicle operations. BOT testing is conducted when a vehicle is new and the EOT testing is conducted after a vehicle has completed approximately 160,000 miles of on-road accelerated testing. The battery laboratory test results include those from the Static Capacity Test and the Hybrid Pulse Power Characterization (HPPC) Test. ${ }^{3}$ Vehicle test results include those from Acceleration Testing and the Fuel Economy Testing. ${ }^{4}$

The battery and vehicle testing was performed by the Electric Transportation Engineering Corporation. The Idaho National Laboratory and Electric Transportation Engineering Corporation conduct the Advanced Vehicle Testing Activity for DOE's Vehicle Technologies Program.

\subsection{Static Capacity Test Results}

Results for the laboratory BOT and EOT Static Capacity Test are provided as follows:

\begin{tabular}{|l|c|r|r|r|r|}
\hline & \multicolumn{1}{|c|}{ Test Date } & \multicolumn{1}{c|}{$\begin{array}{c}\text { Odometer } \\
(\mathrm{mi})\end{array}$} & $\begin{array}{c}\text { Rated } \\
\text { Capacity (Ah) }\end{array}$ & $\begin{array}{c}\text { Measured } \\
\text { Capacity (Ah) }\end{array}$ & $\begin{array}{c}\text { Measured } \\
\text { Energy (Wh) }\end{array}$ \\
\hline BOT & December 12,2007 & 656 & 6.5 & 5.70 & 1,480 \\
\hline EOT & September 4, 2009 & 161,052 & 6.5 & 5.63 & 1,460 \\
\hline Difference & - & 160,396 & - & $-0.07(-1.2 \%)$ & $-20(-1.4 \%)$ \\
\hline
\end{tabular}

Figure 1 shows battery voltage versus energy discharged. This graph illustrates voltage values during constant current discharge versus cumulative energy discharged from the battery at a $\mathrm{C} / 1$ constant current discharge rate at BOT and EOT.

\footnotetext{
${ }^{3}$ Static Capacity and HPPC test procedures were performed based on the FreedomCAR Battery Test Manual for Power-Assist Hybrid Electric Vehicles, DOE/ID-11069, October 2003, Procedures 3.2 and 3.3, respectively. The measured capacity at the time of testing was used to determine the magnitude of current during the HPPC test.

${ }^{4}$ Acceleration Testing and Fuel Economy Testing procedures were performed in accordance with the Advanced Vehicle Testing Activity HEVAmerica test procedures ETA-HTP02 and ETA-HTP03, respectively.
} 


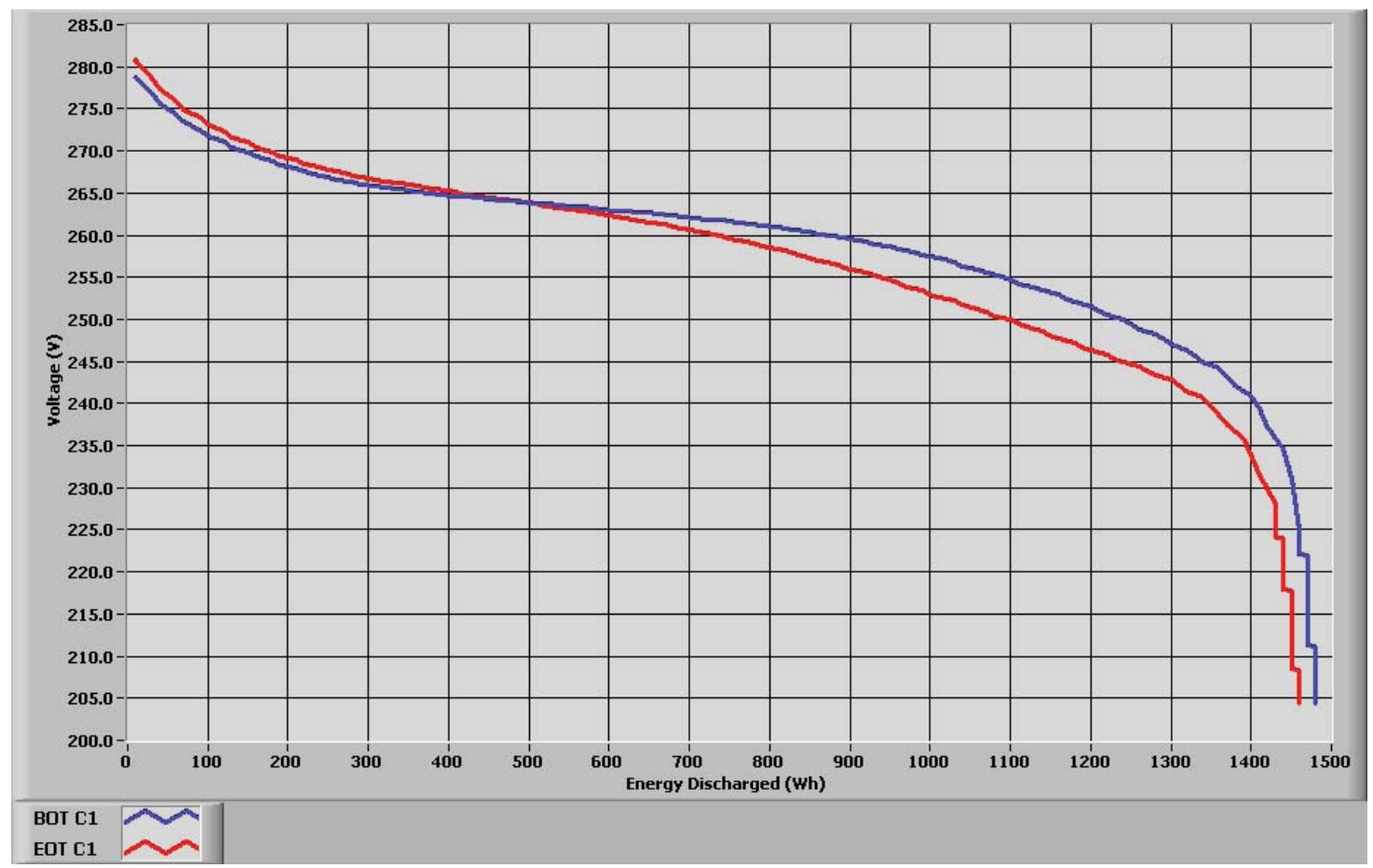

Figure 1. Voltage versus energy discharged.

\subsection{Hybrid Pulse Power Characterization Test Results}

HPPC test results are summarized as follows:

\begin{tabular}{|l|r|r|r|r|r|r|}
\hline & $\begin{array}{c}10 \mathrm{~s} \\
\text { Discharge } \\
\text { Power }(\mathrm{kW})\end{array}$ & $\begin{array}{c}1 \mathrm{c} \\
\text { Discharge } \\
\text { Power }(\mathrm{kW})\end{array}$ & $\begin{array}{c}10 \mathrm{~s} \text { Charge } \\
\text { Power } \\
(\mathrm{kW})\end{array}$ & $\begin{array}{c}\text { 1s Charge } \\
\text { Power } \\
(\mathrm{kW})\end{array}$ & $\begin{array}{c}\text { Maximum } \\
\text { Cell Voltage } \\
(\mathrm{V})\end{array}$ & $\begin{array}{c}\text { Minimum } \\
\text { Cell } \\
\text { Voltage (V) }\end{array}$ \\
\hline BOT & 26.0 & 36.0 & 25.5 & 35.5 & 1.5 & 1.0 \\
\hline EOT & 23.5 & 33.3 & 23.1 & 34.2 & 1.5 & 1.0 \\
\hline Difference & $-2.5(-9.6 \%)$ & $-2.7(-7.5 \%)$ & $-2.4(-9.4 \%)$ & $-1.3(-3.7 \%)$ & - & - \\
\hline
\end{tabular}

Figures 2 and 4 illustrate the battery's charge and discharge pulse resistance graphs, showing internal resistance over a range of 10 to $90 \%$ depth of discharge. Each curve represents the specified HPPC BOT or EOT resistance at the end of the 10-second pulse interval.

Figures 3 and 5 illustrate the battery's charge and discharge pulse power graphs, showing the pulse power over a range of 10 to $90 \%$ depth of discharge. Each curve represents the specified HPPC BOT or EOT available power at the end of the 10 -second pulse interval at the cell voltage limits. 


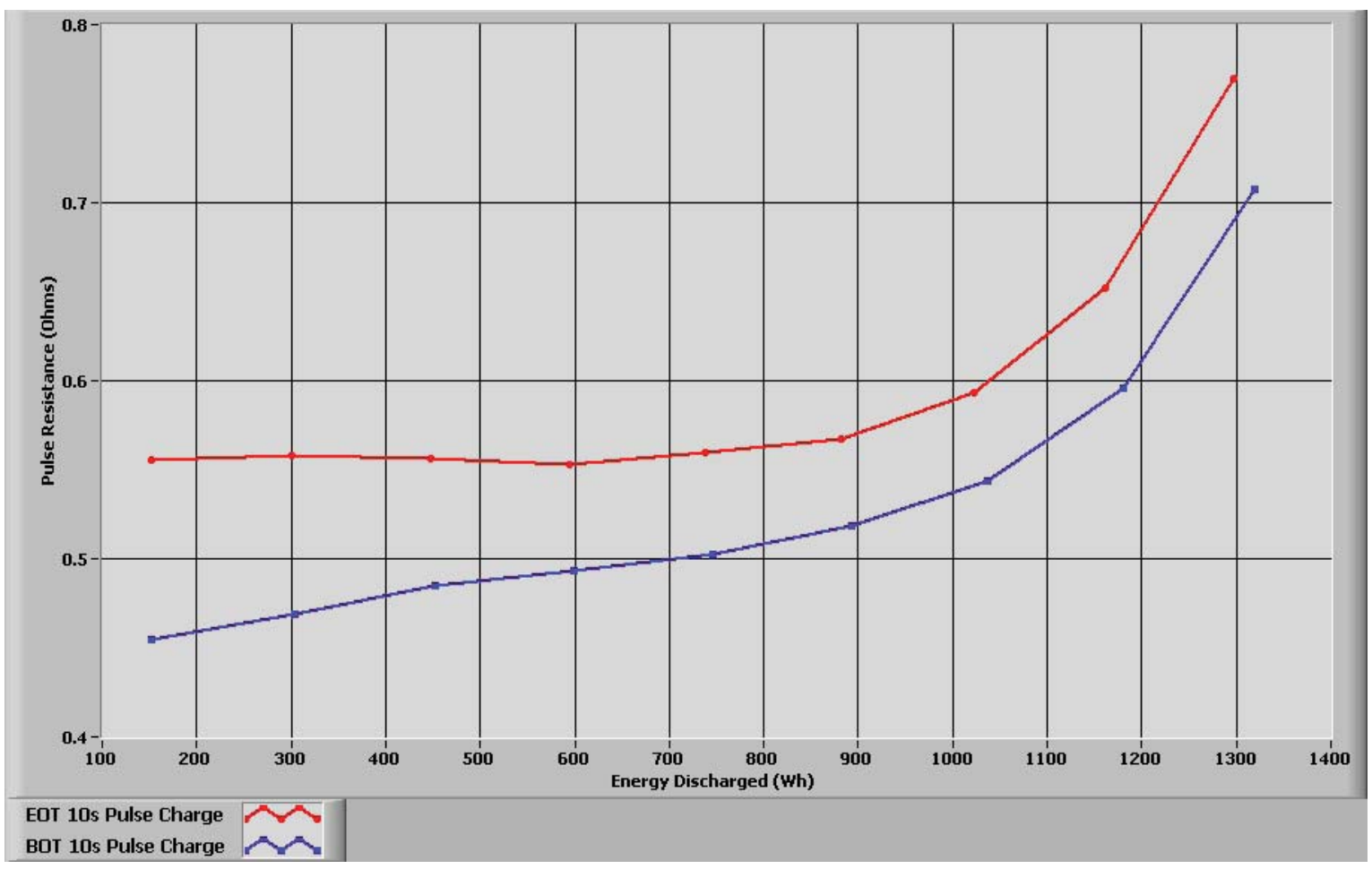

Figure 2. Ten-second charge pulse resistance versus energy discharged.

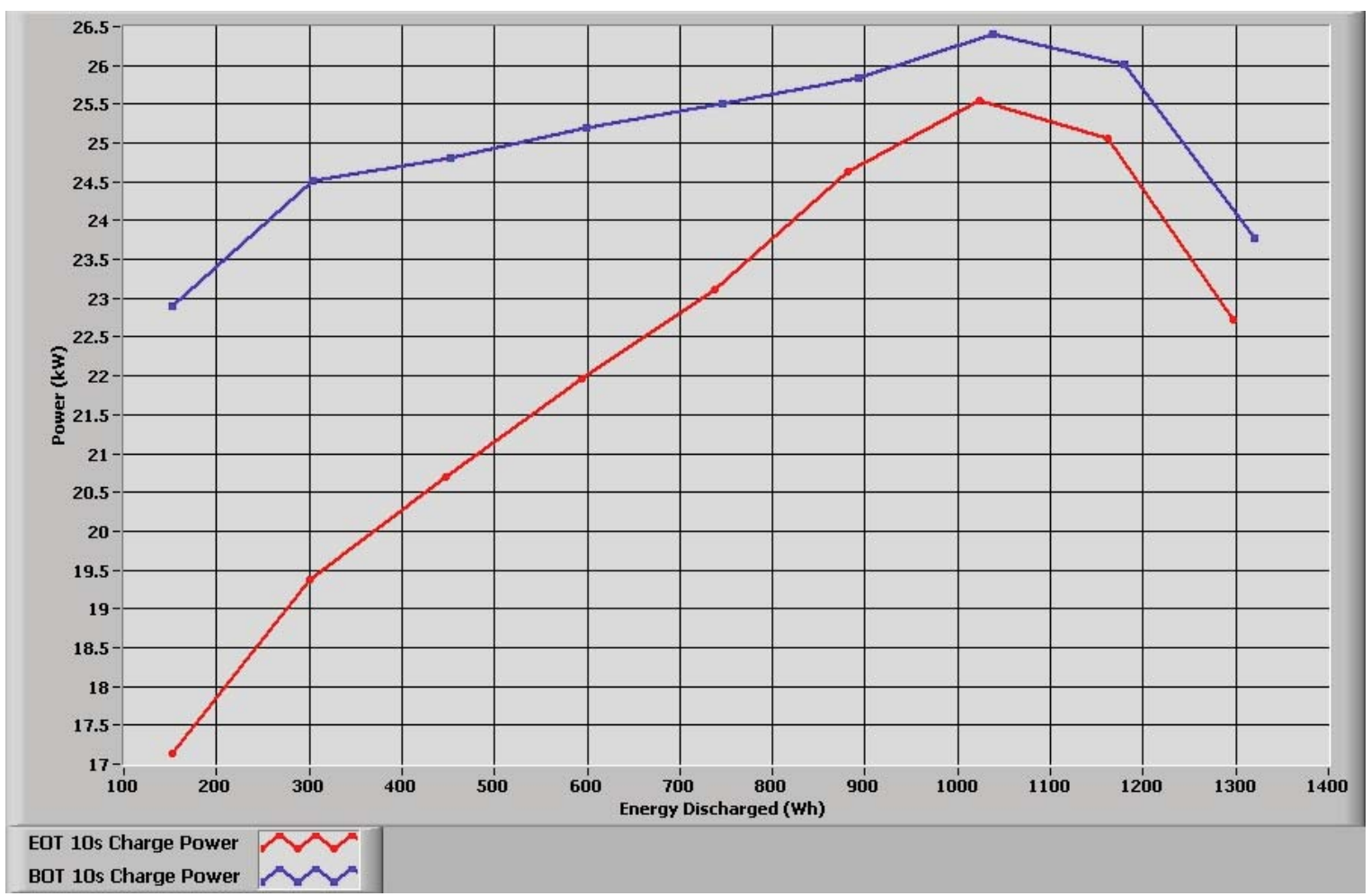

Figure 3. Ten-second charge pulse power versus energy discharged. 


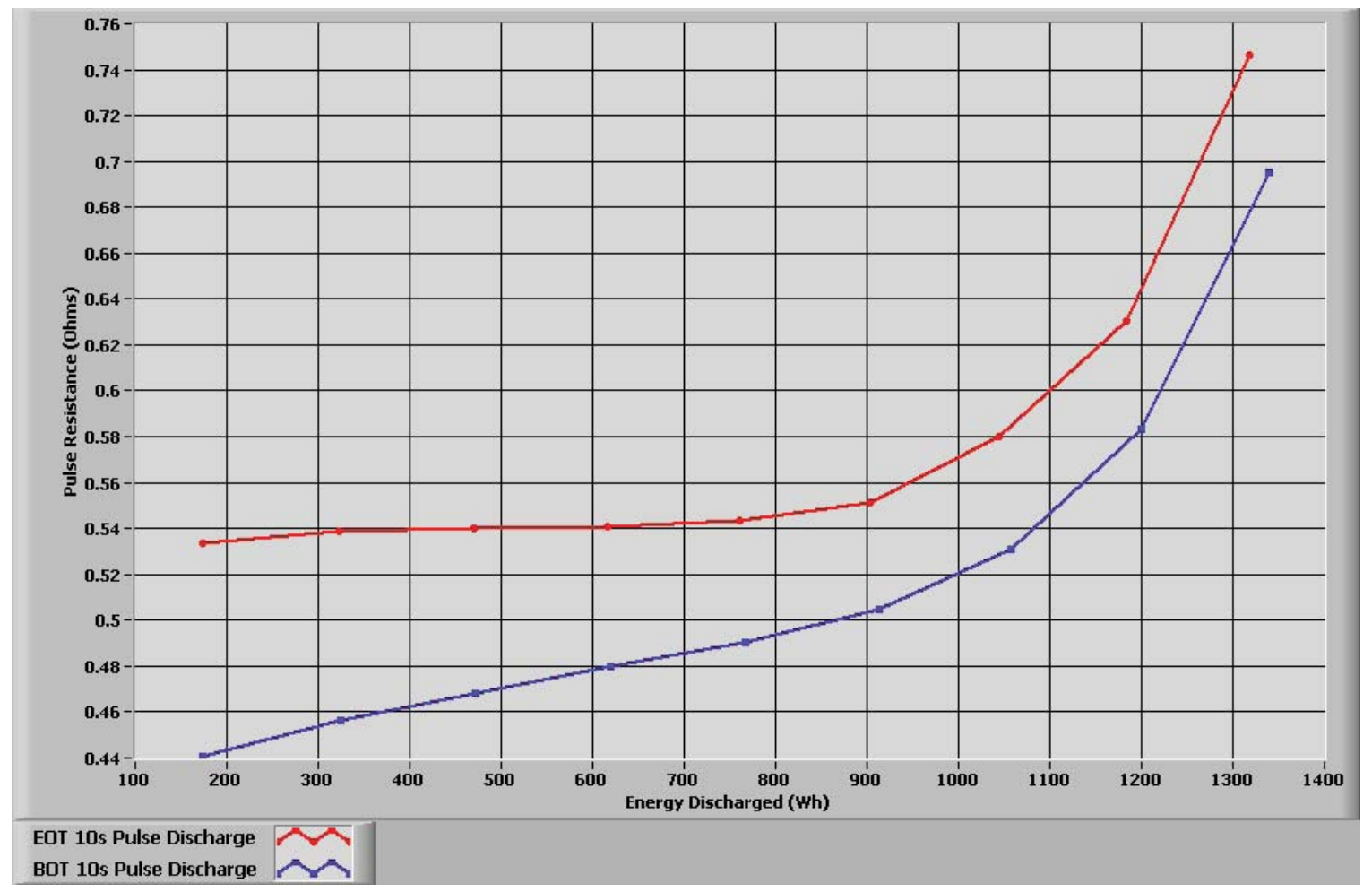

Figure 4. Ten-second discharge pulse resistance versus energy discharged.

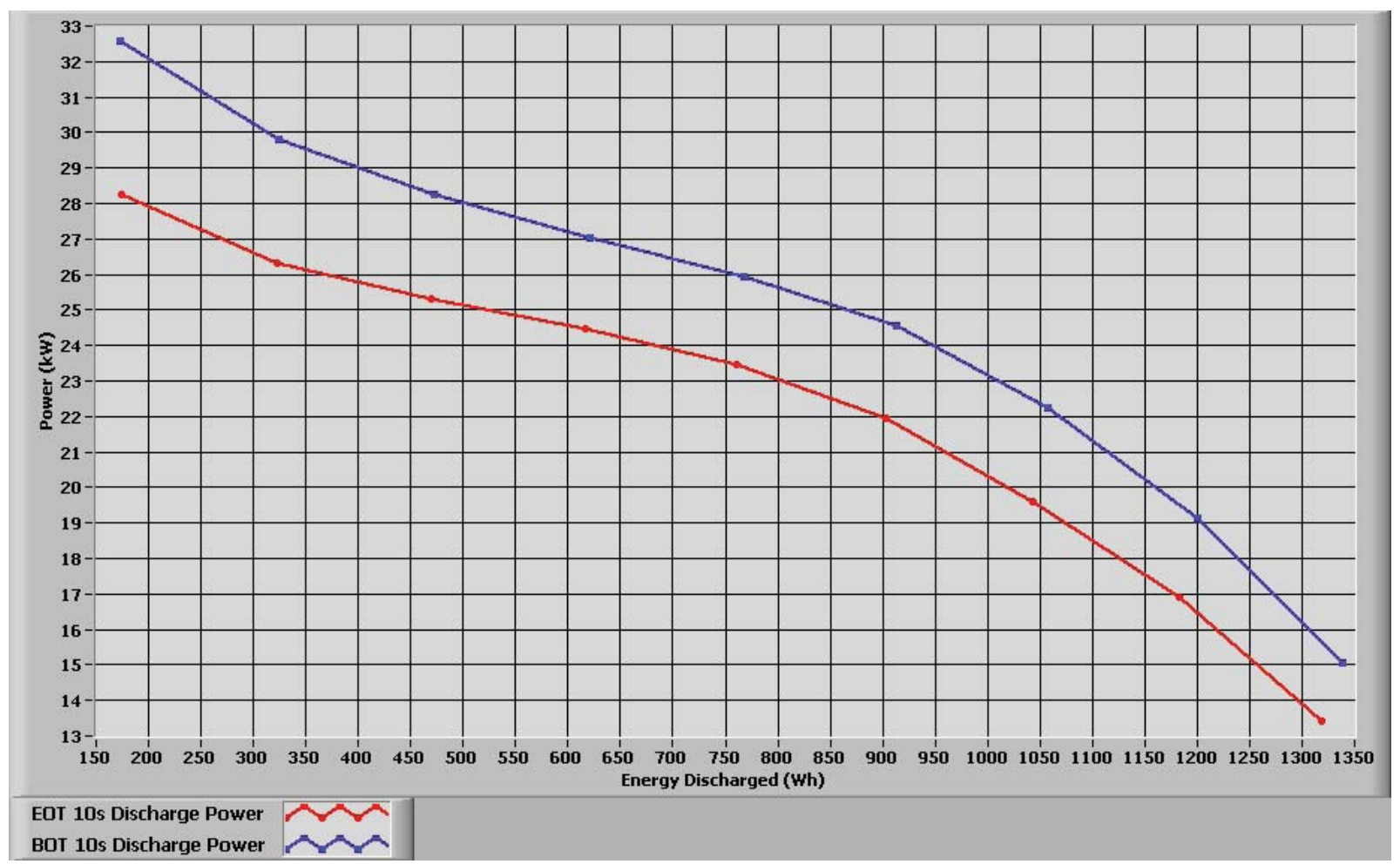

Figure 5. Ten-second discharge pulse power versus energy discharged. 
Figure 6 is a plot of the battery's BOT and EOT HPPC 10-second pulse power values as a function of state of charge (SOC). The graph shows the power values over the range of SOC and DOE targets of 25$\mathrm{kW}$ discharge power and $20-\mathrm{kW}$ regen power for a hybrid minimum power assist battery. The BOT battery test meets the DOE power performance targets for battery SOC range of 90 to $43.5 \%$. The EOT battery test meets the DOE power performance targets for battery SOC range of 75 to $66 \%$.

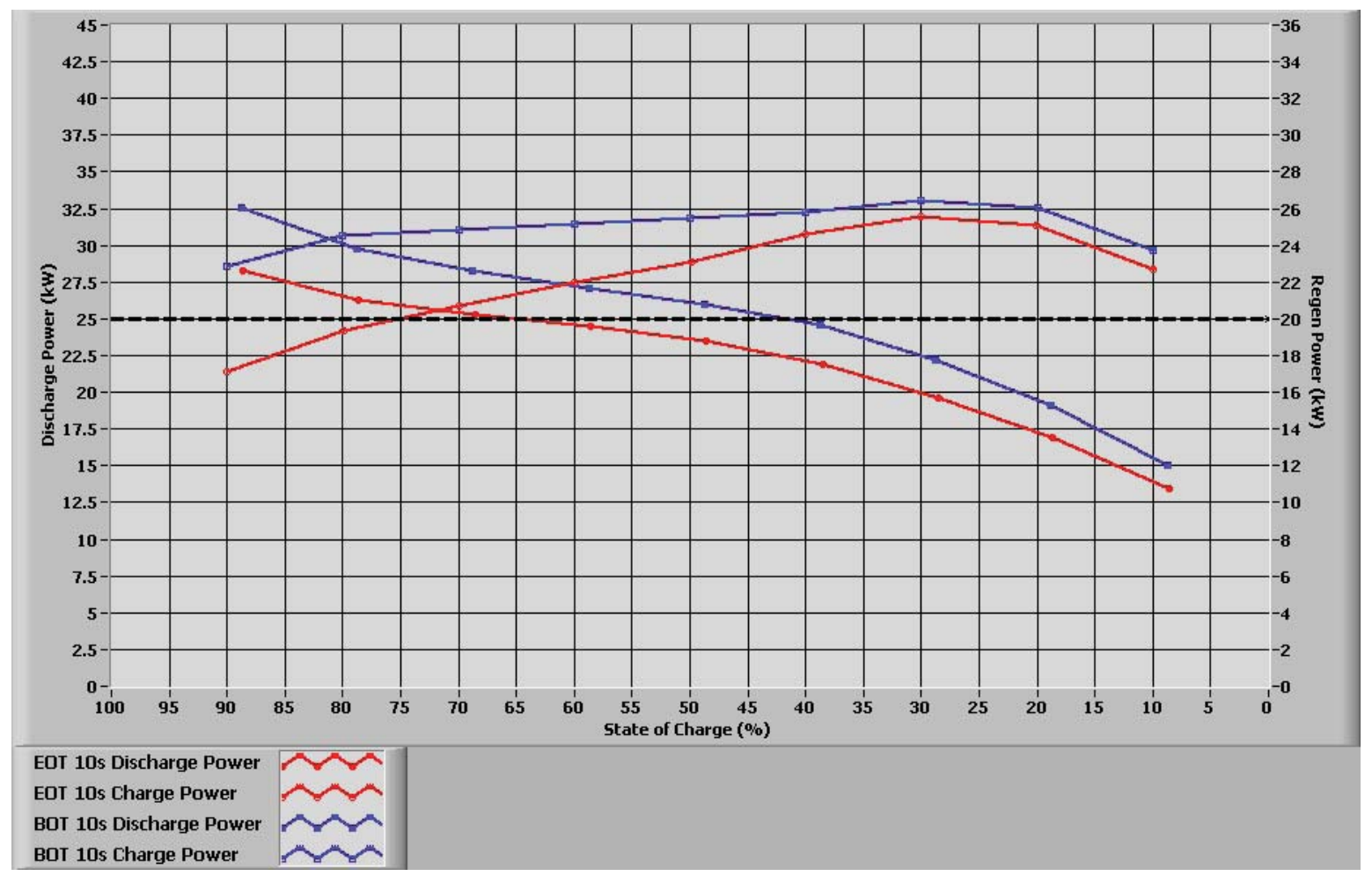

Figure 6. Peak power values with Department of Energy targets.

Figure 7 is a plot of the battery's BOT and EOT useable energy as a function of power. The x-axis indicates a desired discharge or charge power level and the y-axis indicates the useable energy at that power. The dashed horizontal line shows the DOE minimum power assist HEV energy target of $300 \mathrm{Wh}$. The dashed vertical line shows the DOE minimum power assist power performance target of $25 \mathrm{~kW}$. The Altima battery's BOT useable energy curve falls above and to the right of the intersection of the DOE energy and power performance targets. The maximum power that can be delivered while meeting the DOE energy target is $29.3 \mathrm{~kW}$ at $300 \mathrm{Wh}$. The maximum energy that can be delivered while meeting the DOE power target is $325 \mathrm{Wh}$ at $29 \mathrm{~kW}$. This indicates that at the time of BOT testing, the Altima battery performance was above DOE targets. The Altima battery's EOT useable energy curve falls above and to the left of the intersection of the DOE energy and power performance targets. The maximum power that can be delivered while meeting the DOE energy target is $24.3 \mathrm{~kW}$ at $300 \mathrm{Wh}$. The battery does not meet the DOE power performance target for any calculated energy value. This indicates that at the time of EOT testing, the Altima battery performance was below DOE targets. 


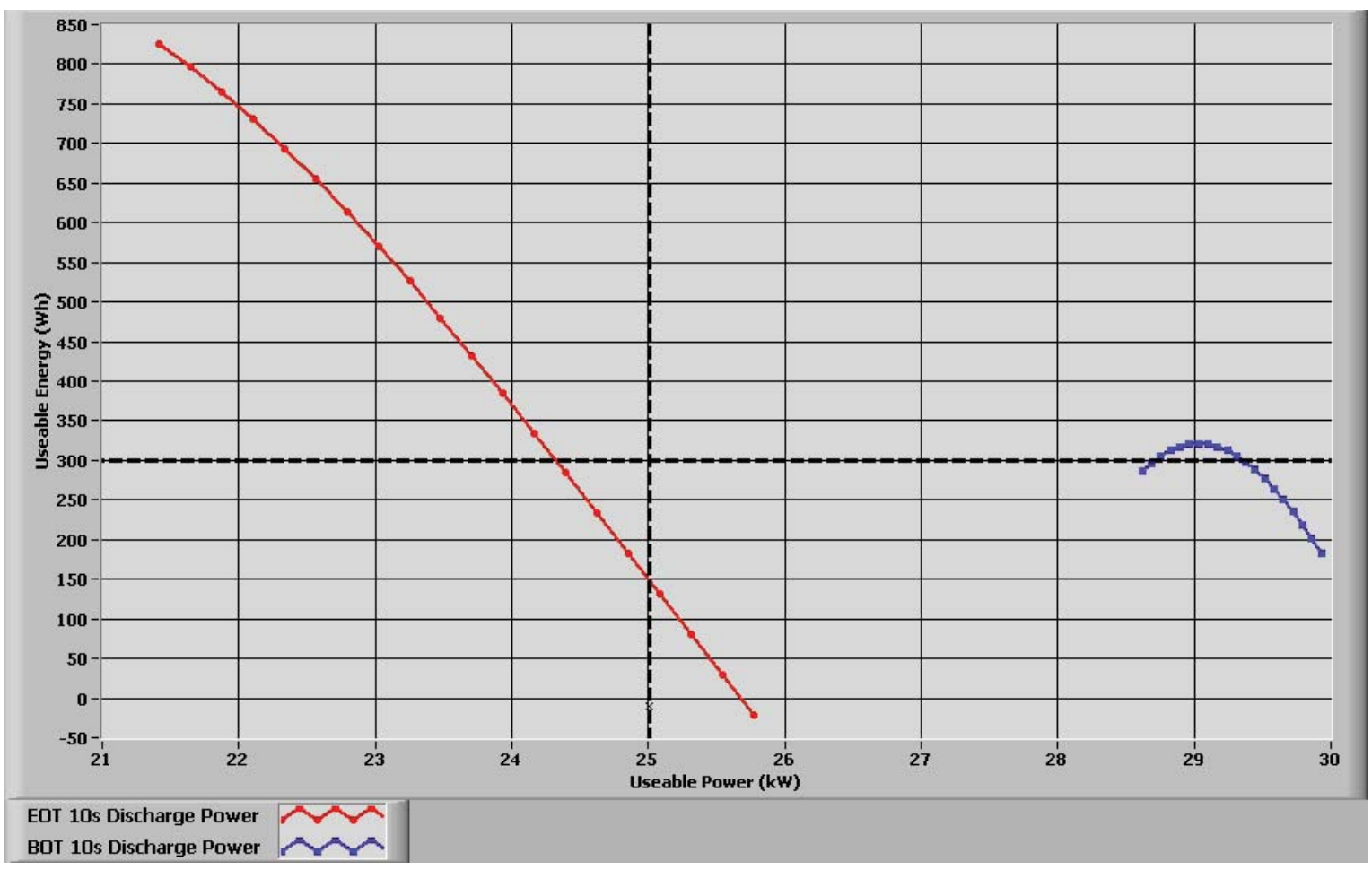

Figure 7. Useable energy.

\subsection{Acceleration Test Results}

BOT and EOT results from vehicle on-track acceleration tests are summarized as follows:

\begin{tabular}{|l|c|c|c|r|r|r|}
\hline & $\begin{array}{c}\text { Average } \\
\text { Discharge } \\
\text { Power Over } \\
10 \mathrm{~s}(\mathrm{kw})\end{array}$ & $\begin{array}{c}\text { Energy } \\
\text { Discharged } \\
\text { at 1 Mile } \\
(\mathrm{Wh})\end{array}$ & $\begin{array}{c}\text { Capacity } \\
\text { Discharged } \\
\text { at 1 Mile } \\
(\mathrm{Ah})\end{array}$ & $\begin{array}{c}\text { Average } \\
\text { Power } \\
\text { Over 1 } \\
\text { Mile }(\mathrm{kW})\end{array}$ & $\begin{array}{c}\text { Minimum } \\
\text { Discharge } \\
\text { Pack Voltage } \\
(\mathrm{V})\end{array}$ & $\begin{array}{c}\text { Minimum } \\
\text { Discharge } \\
\text { Cell Voltage } \\
(\mathrm{V})\end{array}$ \\
\hline BOT & 25.8 & 189 & 0.88 & 17.1 & 209.8 & 1.03 \\
\hline EOT & 25.6 & 222 & 0.97 & 18.6 & 219.7 & 1.08 \\
\hline
\end{tabular}

Figure 8 shows battery power versus time during the 1-mile acceleration test at EOT and BOT. This graph is the basis for power calculations over the specified time interval and the cumulative discharged energy capacity during the duration of the test. Initially, during the acceleration test, the power quickly rams up from about $0 \mathrm{~kW}$ to a peak value. This initial peak power is used as a reference point for the complement of the power analyses. Ideally, the power would remain constant; however, battery system dynamics, which may include battery control logic, cause the voltage to drop, resulting in a gradual reduction in power.

Figure 9 shows battery voltage versus time during the 1-mile acceleration test at BOT and EOT. Values are analyzed to determine the battery control module's minimum allowable voltage if possible. Although the test may not yield a definitive minimum voltage value, it can yield an approximation for comparison to the HPPC analysis results. This graph also shows the impact of power electronics and battery controller on the voltage response. 


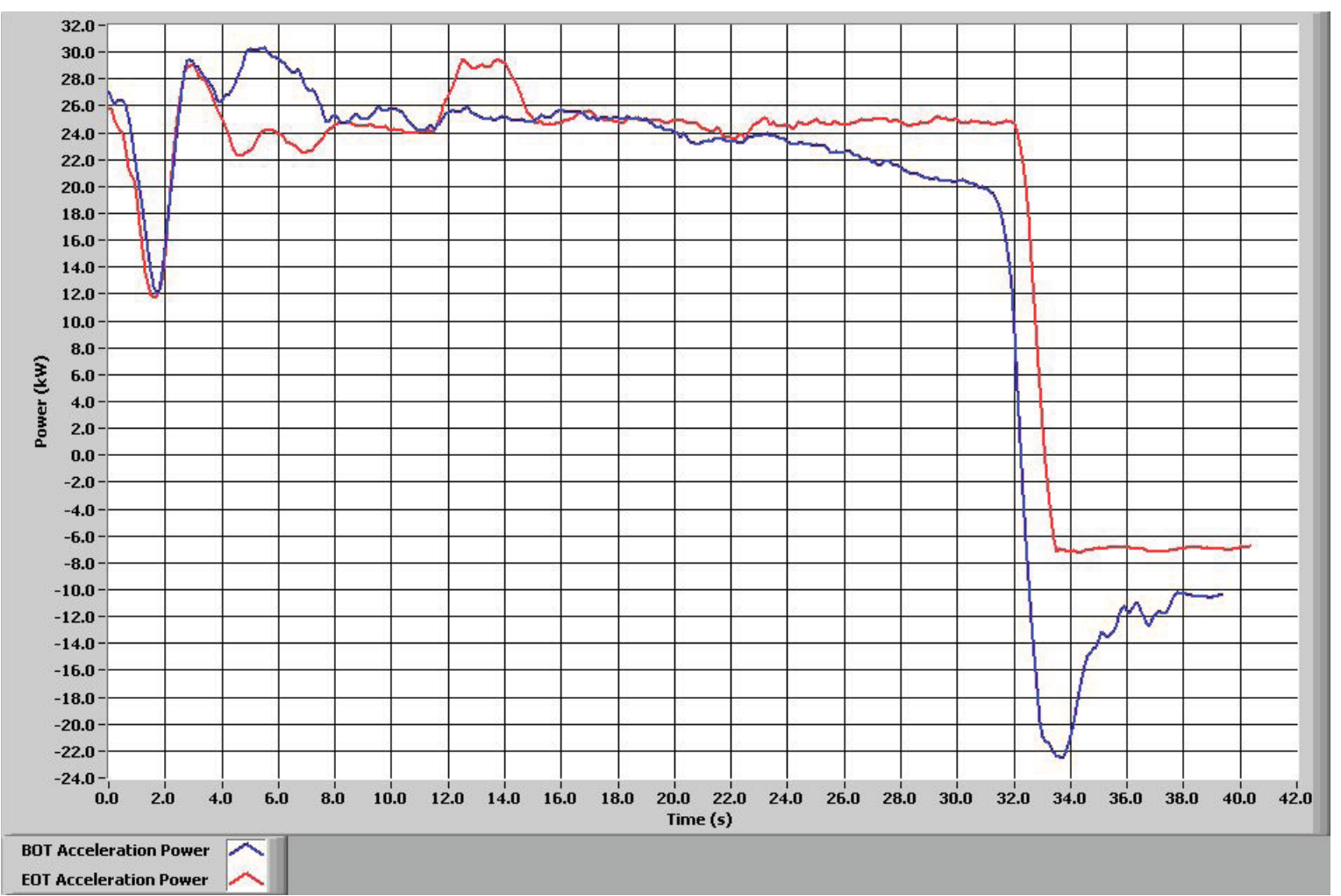

Figure 8 . Battery power versus time.

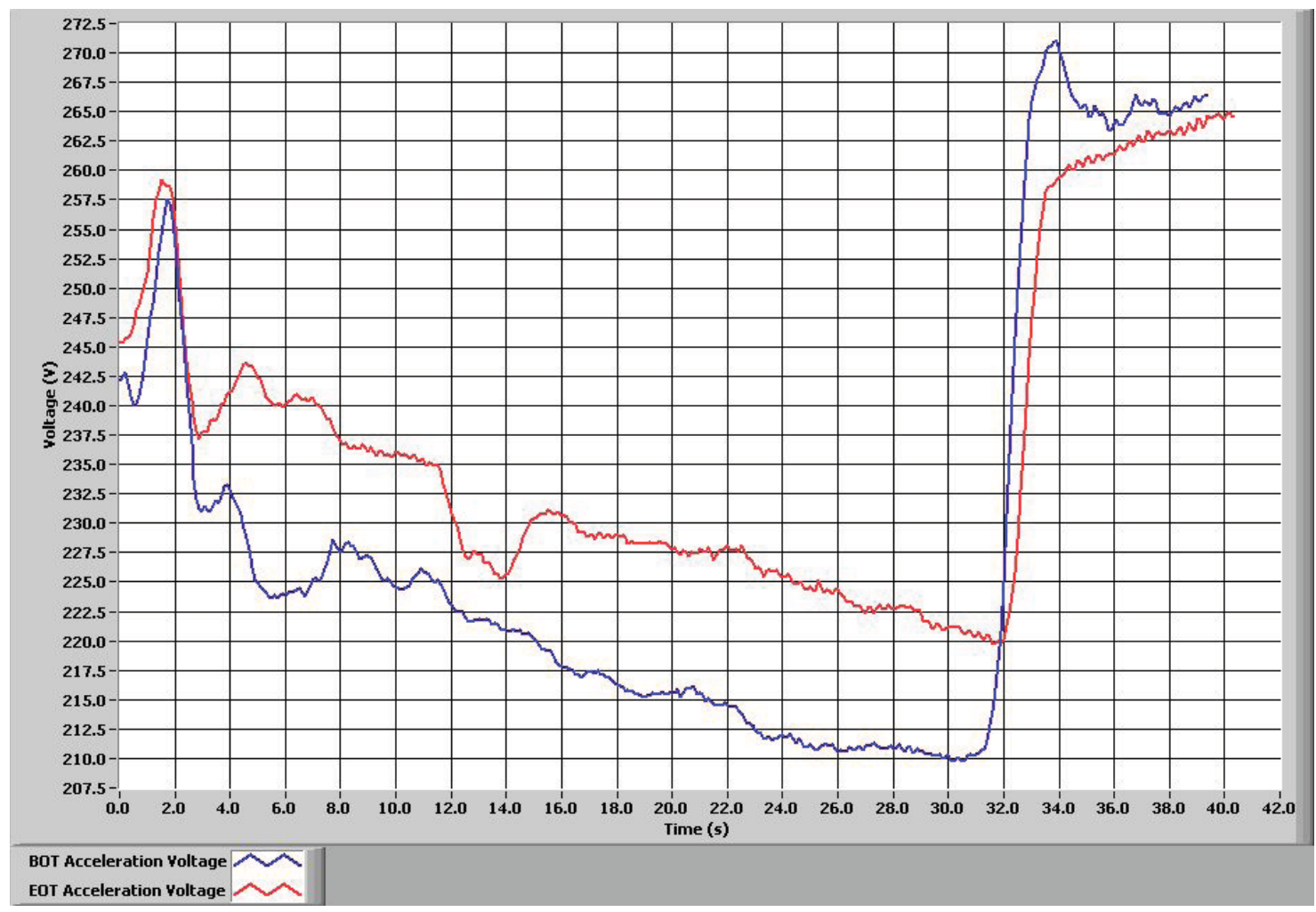

Figure 9. Battery voltage versus time. 
Figure 10 shows battery current versus time during the 1-mile acceleration test at BOT and EOT. This graph also is the basis for determining the discharged capacity during the test run. Lastly, the power results in Figure 8 can be obtained by simply multiplying the voltage values from Figure 9 by the current values in Figure 10.

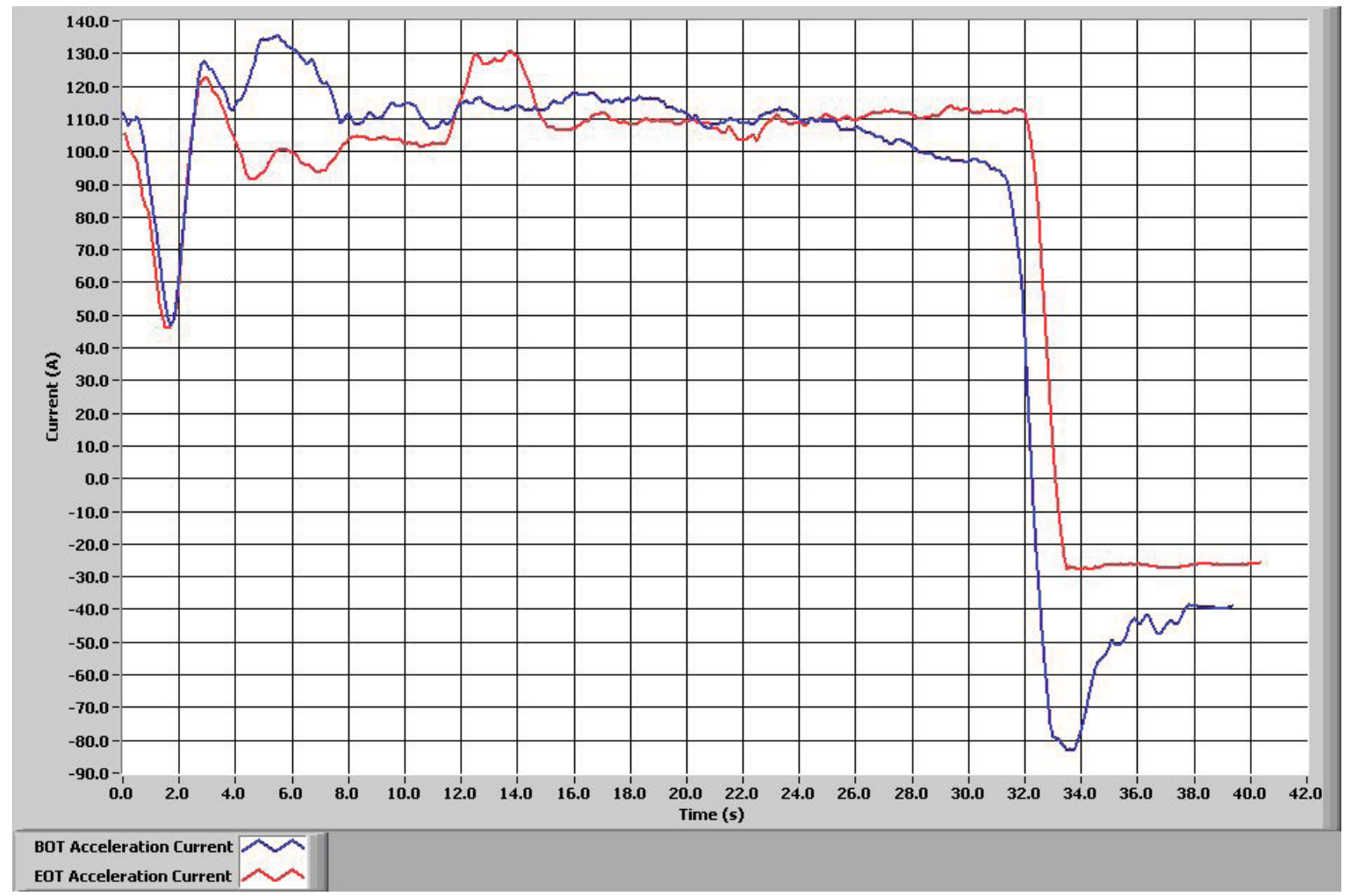

Figure 10. Battery current versus time.

\subsection{Fuel Economy Test Results}

Battery performance results from testing conducted on an electric dynamometer (Urban Dynamometer Drive Schedule ${ }^{5}$ ) at BOT and average fuel economy recorded while the vehicle was operating in an on-road fleet ${ }^{6}$ approximately $53 \%$ in city and $47 \%$ in highway ${ }^{7}$ types of routes are summarized as follows:

Peak Discharge Power (kW)

Peak Regenerative Power (kW)

Measured Discharge Capacity (Ah)

Measured Regenerative Capacity (Ah)

Discharge/Charge Ratio
37.6 Maximum Charge Pack Voltage (V)

29.4 Maximum Charge Cell Voltage (V)

8.69 Minimum Discharge Pack Voltage (V)

9.16 Minimum Discharge Cell Voltage (V)

0.949 Average Fuel Economy (mpg)
304.5

29.8

\footnotetext{
${ }^{5}$ Urban Dynamometer Drive Schedule was performed as defined by the Environmental Protection Agency. The definition of the Urban Dynamometer Drive Schedule can be found at http://www.epa.gov/nvfel/methods/uddsdds.gif.

${ }^{6}$ On-road fleet testing is performed by the Electric Transportation Engineering Corporation (in conjuncture with JP Morgan Chase Bank's courier services). The vehicles are driven a combination of city and highway routes by several different drivers to expedite the amount mileage needed to reach EOT.

${ }^{7}$ The type of on-road driving routes for the two Altima HEVs is summarized as $53 \%$ city and $47 \%$ highway in the Advanced Vehicle Testing Activity's Final Fleet Testing Results fact sheet that can be found at http://avt.inel.gov/pdf/hev/finalfact2007NissanAltima.pdf.
} 
Figure 11 illustrates the vehicle motive power histogram throughout one of the tested drive schedules. Motive power is a calculated value representing instantaneous theoretical positive wheel power required to complete the urban drive cycle. The $\mathrm{x}$-axis of the bar graph represents the center point of a particular power level. For example, the first bar graph with a power of 2 represents all power values between 1 and $3 \mathrm{~kW}$ (lower boundary is inclusive and upper boundary is non-inclusive). The corresponding y-value at this power level is the percent time at this particular power band throughout the entire drive cycle (regeneration power and zero power non-inclusive). Directly beside the vehicle motive power value is the same analysis performed on the battery output power for a particular power band. While the occurrences of vehicle motive power and battery discharge power in each power band in Figure 11 are not necessarily coincident in time, it possible to conclude from the overall shapes of the distributions that the battery provides a substantial fraction of the required vehicle motive power. Efficiency losses between the battery and wheels are not included in this figure, and naturally reduce the contribution of the battery to vehicle motive power.

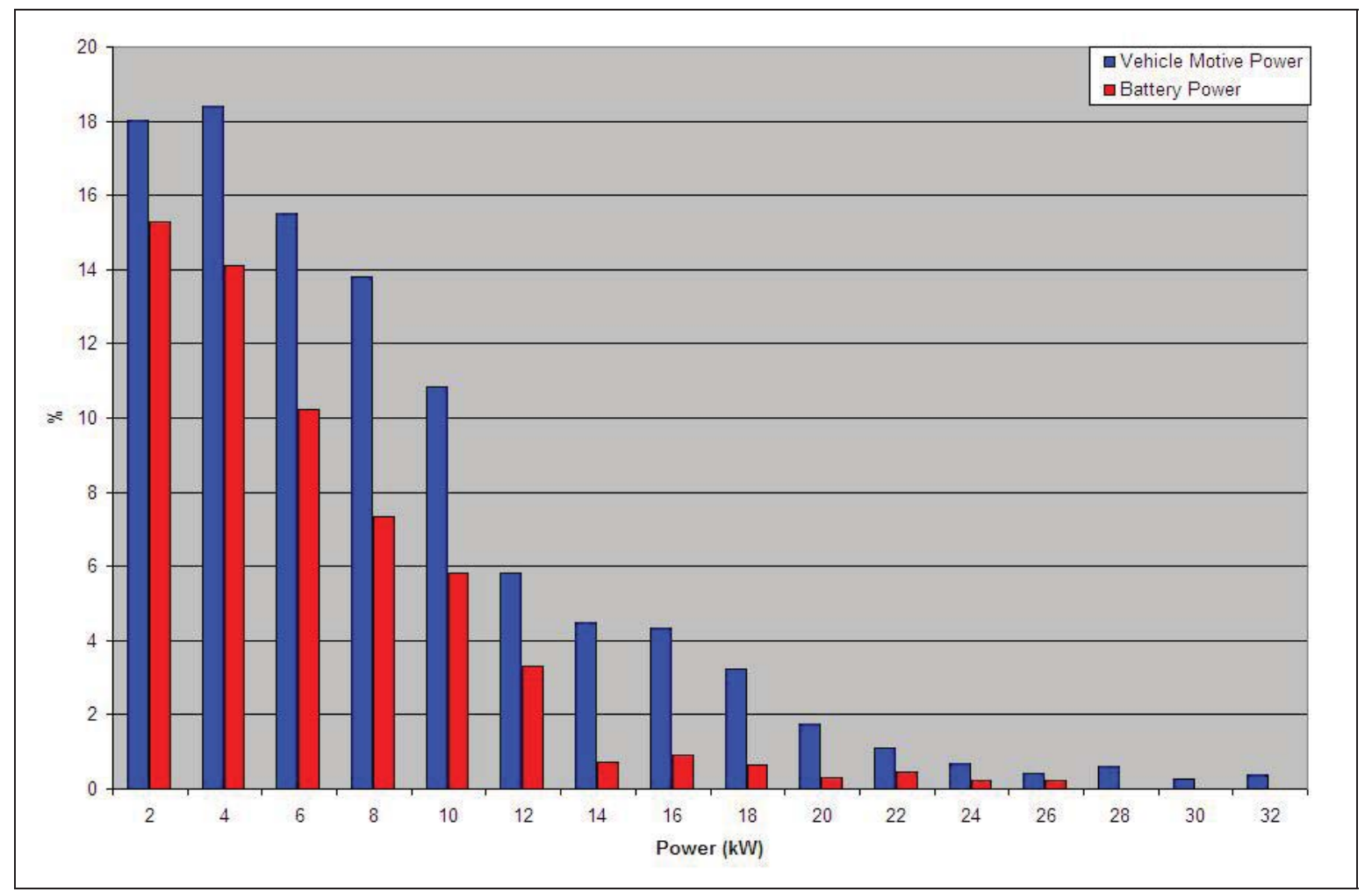

Figure 11. Percent time at motive power level.

Figure 12 illustrates the vehicle regenerative braking power histogram throughout one of the tested urban drive cycles. Regenerative braking power is a calculated value that represents the theoretical negative wheel power required to decelerate the vehicle on the urban drive cycle. Figure 12 compares the distributions of available braking power and actual battery charge power. The overall shapes of the distributions indicate that the battery captures a substantial fraction of the vehicle power available during braking. 


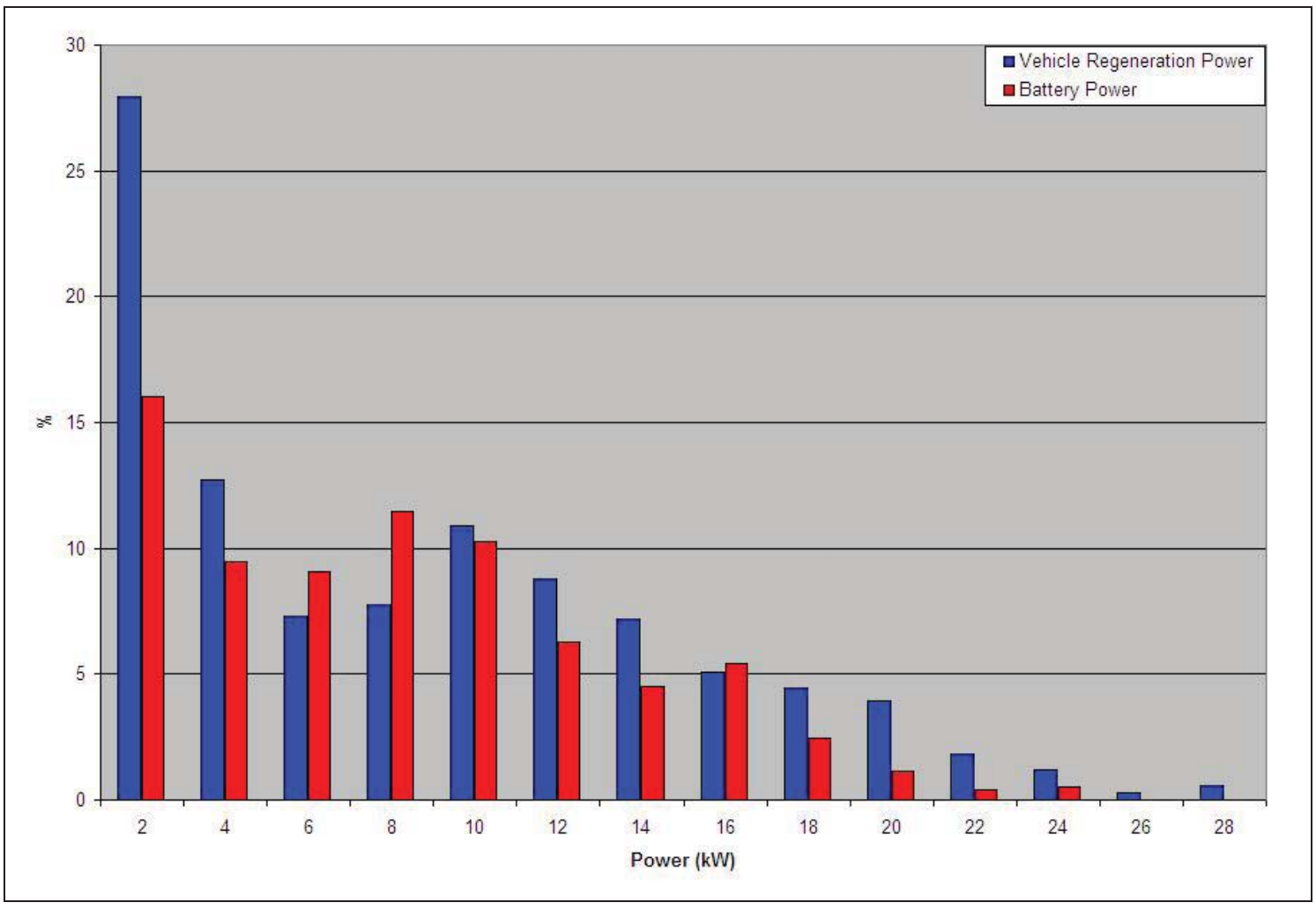

Figure 12. Percent time at regenerative power level.

Figure 13 is a pie chart showing the sources of battery charging. The chart shows the percent of battery charging time when the battery experienced ideal versus non-ideal charging. Ideal charging refers to regenerative braking during deceleration where the deceleration force is in excess of the vehicle drag forces. On a non-hybrid vehicle, this would require the brakes to be pressed and excess energy would be converted to heat at the brakes. In a hybrid vehicle, a portion of this excess energy can be captured and stored for later use. Because this charge method is capturing energy that is normally lost, the charge event is considered ideal. The second charging type is called non-ideal because the vehicle charges the battery by the use of the internal combustion engine and generator. This can happen during acceleration, cruising, or deceleration when excess engine load is available or when the battery state of charge has dropped below a minimum level. . This is non-ideal because the internal combustion engine charges the battery. In some cases, this can be beneficial for overall fuel economy by maintaining optimum load on the engine to increase efficiency; however, it is still considered non-ideal because gasoline is used to charge the batteries.

Figure 14 is a pie graph that shows the percent of vehicle regeneration energy captured in the battery. By calculating total vehicle energy available at the wheels during an ideal charge event and performing a direct comparison of energy into the battery, the percent energy into the battery can be calculated. In addition, system losses can be determined as the difference between energy available from the vehicle and energy into the battery. Although each component of loss cannot be determined, the total system loss can be measured by this method. Also, it should be noted that this calculation does not take into account losses at the battery due to charge inefficiency. This measurement is merely a calculation of how efficiently the vehicle charging mechanism is able to capture regeneration energy during an ideal charge event. $^{8}$

\footnotetext{
${ }^{8}$ Results shown in Figures 13 and 14 do not consider the case when non-ideal engine charging occurs during a regenerative braking event. The impact of this case during the UDDS test is assumed to be negligible.
} 


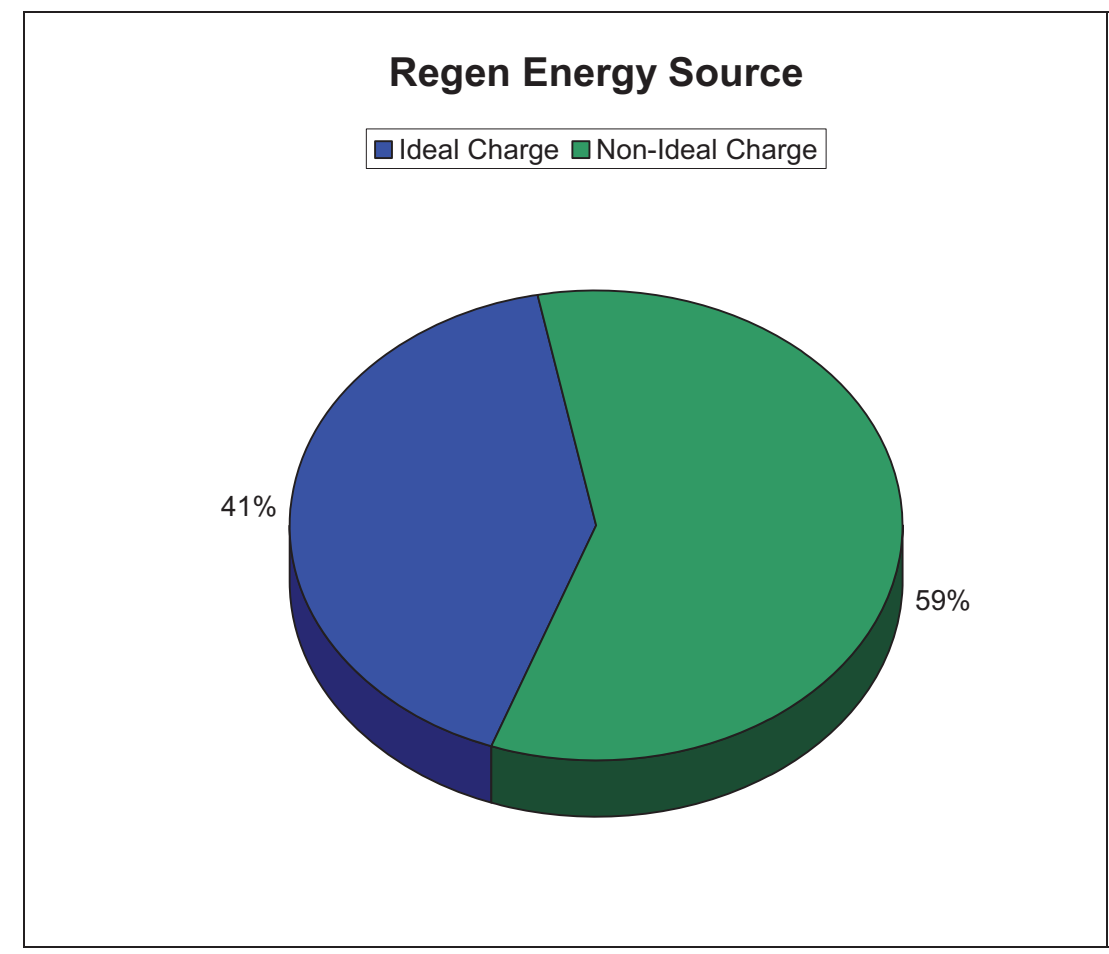

Figure 13. Regenerative energy source comparison.

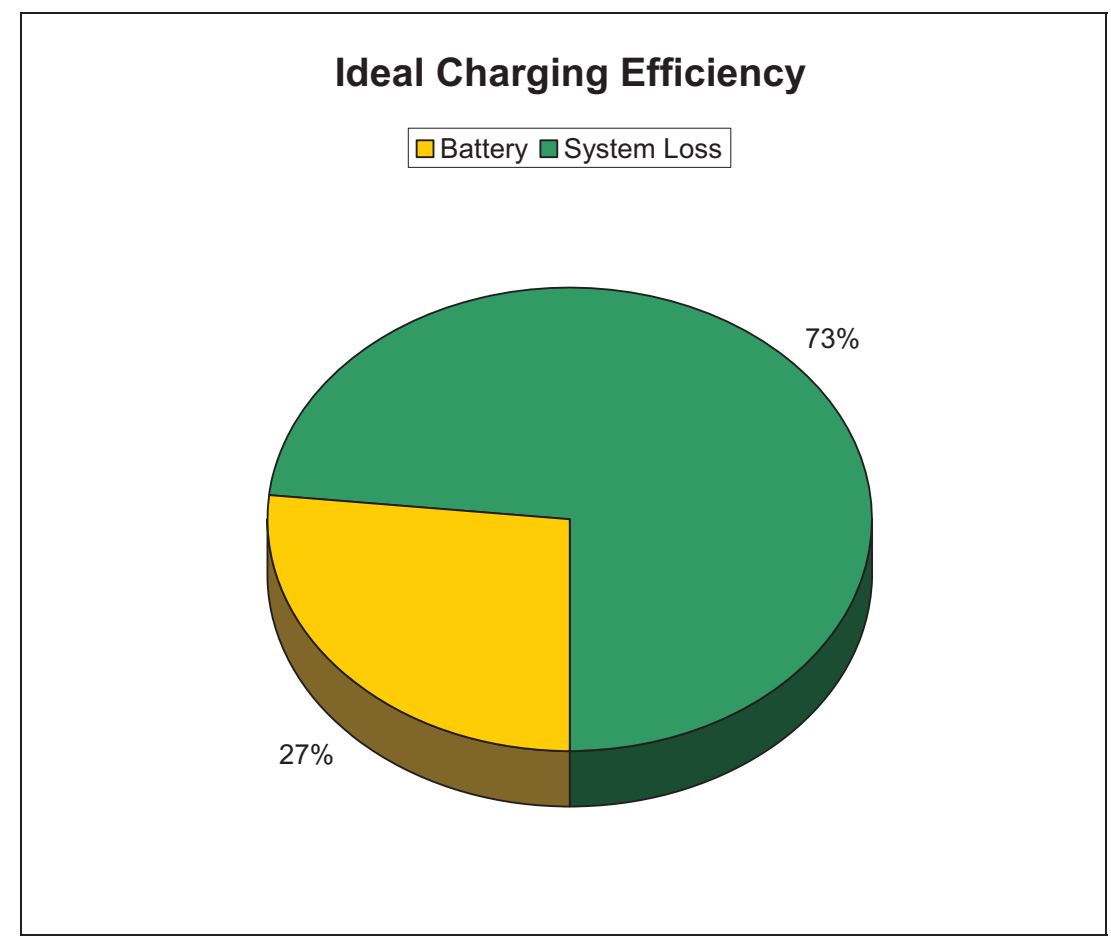

Figure 14. Ideal regenerative energy destination.

Figure 15 presents the combined monthly fuel economy and cumulative fuel economy for the two Altima HEVs in on-road fleet testing. The monthly fuel economy is derived from the amount of fuel consumed, based on fleet fueling records, and the distance traveled, based on vehicle odometer readings, for each vehicle within that month. The cumulative fuel economy is a running total of each month's fuel 
consumption and distance traveled. While there is no way, with only this data, to directly correlate vehicle fuel economy to operation of the battery pack, it can be seen from Figure 15 that fuel economy for these vehicles remained relatively unchanged over the last 18 months of testing, even with the battery degradation demonstrated by the EOT battery test.

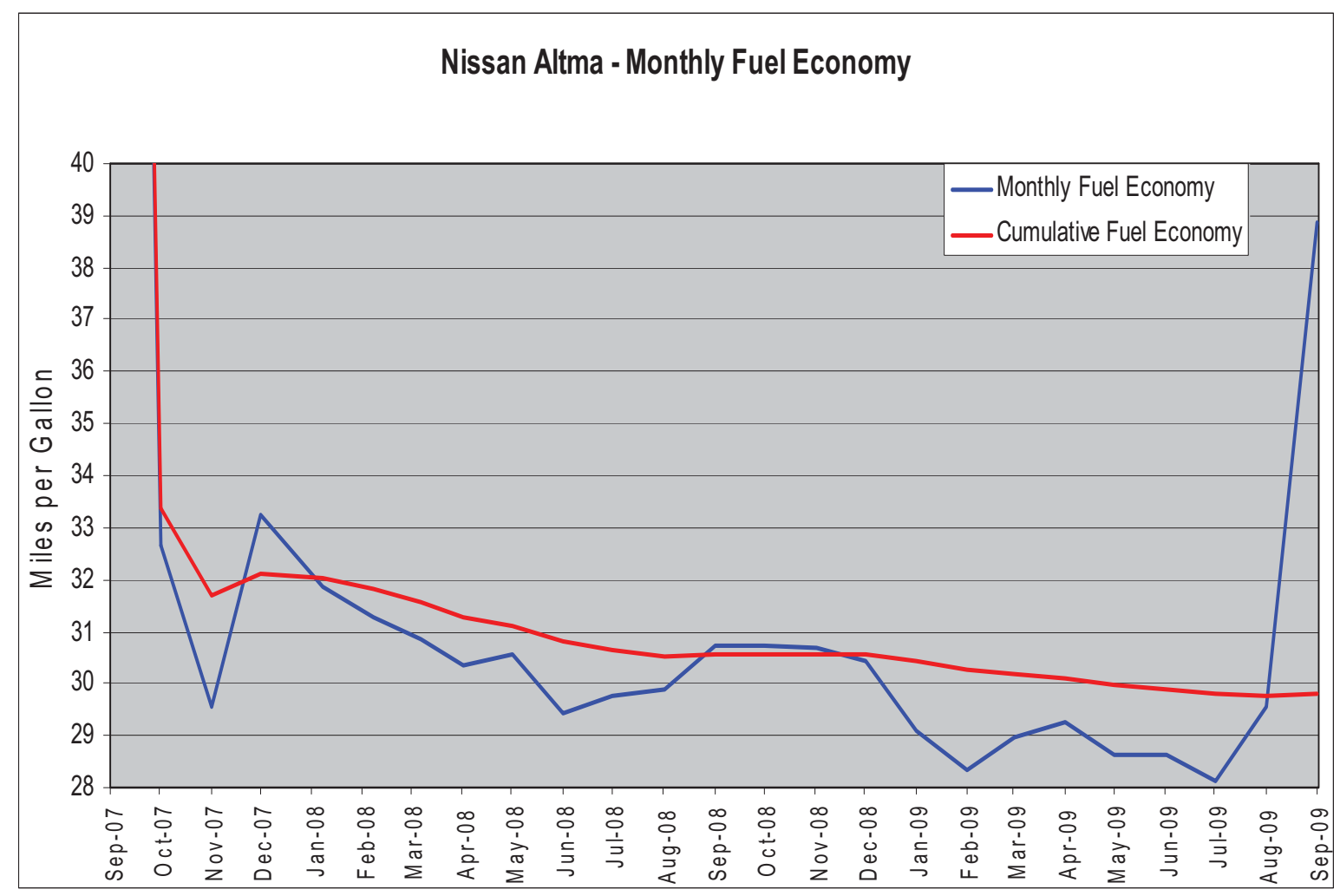

Figure 15. Monthly and cumulative fuel economy.

\subsection{Conclusion}

Nissan Altima number 7982 experienced a 1.2\% degradation in battery capacity and stayed above the DOE performance targets for peak power, but transitioned from above the DOE performance targets at BOT to below at EOT for useable energy during the HPPC testing after 160,000 miles of accelerated testing. 


\section{Appendix A}

\section{Vehicle Specifications and Test Results Summary}

\begin{tabular}{|c|c|}
\hline Vehicle Specifications & Battery Specifications \\
\hline $\begin{array}{l}\text { Manufacturer: Nissan } \\
\text { Model: Altima } \\
\text { Year: } 2007 \\
\text { Number of Motors }{ }^{\text {a }}: 1 \\
\text { Motor Power Rating }{ }^{\text {b }}: 105 \mathrm{~kW} \\
\text { VIN \#: 1N4CL21E27C177982 }\end{array}$ & $\begin{array}{l}\text { Manufacturer: Panasonic EV } \\
\text { Battery Type: Nickel Metal Hydride } \\
\text { Rated Capacity: } 6.5 \mathrm{Ahr}(\mathrm{C} / 3 \text { rate) } \\
\text { Rated Power: } 216 \mathrm{~W} \text { (per cell) } \\
\text { Nominal Pack Voltage: } 244.8 \mathrm{VDC} \\
\text { Nominal Cell Voltage: } 1.2 \mathrm{~V} \\
\text { Number of Cells: } 204\end{array}$ \\
\hline \multicolumn{2}{|c|}{ Beginning-of-Test Vehicle Baseline Performance Test Results ${ }^{c}$} \\
\hline Acceleration Test & Fuel Economy Test \\
\hline $\begin{array}{l}\text { Peak Discharge Power@ } 10 \text { seconds }^{\mathrm{d}}: 25.8 \mathrm{~kW} \\
\text { Peak Discharge Power@1 second } \mathrm{d}^{\mathrm{d}}: 29.4 \mathrm{~kW} \\
\text { Energy Discharged @1 mile }: 189 \mathrm{Whr} \\
\text { Capacity Discharged @ } 1 \text { mile }: 0.88 \mathrm{Ahr} \\
\text { Minimum Discharge Pack Voltage: } 209.8 \mathrm{VDC} \\
\text { Minimum Discharge Cell Voltage: } 1.03 \mathrm{~V}\end{array}$ & $\begin{array}{l}\text { Peak Discharge Power: } 37.62 \mathrm{~kW} \\
\text { Peak Charge Power: } 24.35 \mathrm{~kW} \\
\text { Measured Capacity Discharged } \\
\text { Measured Capacity Regenerated } 8.69 \mathrm{Ahr} \\
\text { Battery Discharge/Charge Ratiog: } 0.949 \\
\text { Maximum Charge Pack Voltage: } 304.5 \mathrm{VDC} \\
\text { Maximum Charge Cell Voltage: } 1.49 \mathrm{Vpc} \\
\text { Minimum Discharge Pack Voltage: } 210.3 \mathrm{VDC} \\
\text { Minimum Discharge Cell Voltage: } 1.03 \mathrm{Vpc}\end{array}$ \\
\hline \multicolumn{2}{|c|}{ End-of-Test Vehicle Baseline Performance Test Results } \\
\hline \multicolumn{2}{|c|}{ Acceleration Test } \\
\hline \multicolumn{2}{|c|}{$\begin{array}{l}\text { Peak Discharge Power @ } 10 \text { seconds }^{\mathrm{d}}: 25.6 \mathrm{~kW} \\
\text { Peak Discharge Power @ } 1 \text { second }^{\mathrm{d}}: 29.0 \mathrm{~kW} \\
\text { Energy Discharged @ } 1 \text { mile } \mathrm{e}^{\mathrm{e}}: 222 \mathrm{Whr} \\
\text { Capacity Discharged @ } 1 \text { mile }: 0.97 \mathrm{Ahr} \\
\text { Minimum Discharge Pack Voltage: } 219.7 \mathrm{VDC} \\
\text { Minimum Discharge Cell Voltage: } 1.08 \mathrm{~V} \\
\end{array}$} \\
\hline \multicolumn{2}{|c|}{ Battery Beginning-of-Test Laboratory Test Results } \\
\hline Hybrid Pulse Power Characterization Test & Static Capacity Test \\
\hline $\begin{array}{l}\text { Peak Pulse Discharge Power @ } 10 \text { seconds }^{\mathrm{h}}: 26.0 \mathrm{~kW} \\
\text { Peak Pulse Discharge Power @ } 1 \text { second }^{\mathrm{h}}: 36.0 \mathrm{~kW} \\
\text { Peak Pulse Charge Power @ } 10 \text { seconds }{ }^{\mathrm{h}}: 25.5 \mathrm{~kW} \\
\text { Peak Pulse Charge Power @ } 1 \text { second }{ }^{\mathrm{h}}: 35.5 \mathrm{~kW} \\
\text { Maximum Cell Charge Voltage: } 1.5 \mathrm{~V} \\
\text { Minimum Cell Discharge Voltage: } 1.0 \mathrm{~V}\end{array}$ & $\begin{array}{l}\text { Measured Average Capacity: } 5.70 \mathrm{Ahr} \\
\text { Measured Average Energy Capacity: 1,480 Whr } \\
\text { Vehicle Odometer: } 656 \text { miles } \\
\text { Date of Test: December 12, } 2007\end{array}$ \\
\hline \multicolumn{2}{|c|}{ Battery End-of-Test Laboratory Test Results } \\
\hline Hybrid Pulse Power Characterization Test & Static Capacity Test \\
\hline $\begin{array}{l}\text { Peak Pulse Discharge Power@ @ } 10 \text { seconds }^{\mathrm{h}}: 23.5 \mathrm{~kW} \\
\text { Peak Pulse Discharge Power @ } 1 \text { second }^{\mathrm{h}}: 33.3 \mathrm{~kW} \\
\text { Peak Pulse Charge Power@ } 10 \text { seconds }^{\mathrm{h}}: 23.1 \mathrm{~kW} \\
\text { Peak Pulse Charge Power@ } 1 \text { second }: 34.2 \mathrm{~kW} \\
\text { Maximum Cell Charge Voltage: } 1.5 \mathrm{~V} \\
\text { Minimum Cell Discharge Voltage: } 1.0 \mathrm{~V}\end{array}$ & $\begin{array}{l}\text { Measured Average Capacity: } 5.63 \mathrm{Ahr} \\
\text { Measured Average Energy Capacity: 1,460 Whr } \\
\text { Vehicle Odometer: } 161,052 \text { miles } \\
\text { Date of Test: September 4, } 2009\end{array}$ \\
\hline
\end{tabular}


Degradation of Battery Over Test Period $^{\mathrm{i}}$

Hybrid Pulse Power Characterization Test

Peak Pulse Discharge Power @ 10 seconds $^{\mathrm{h}}: 2.5 \mathrm{~kW}(9.6 \%)$

Peak Pulse Discharge Power @ 1 second $^{\mathrm{h}}: 2.7 \mathrm{~kW}(7.5 \%)$

Peak Pulse Charge Power@ 10 seconds $: 2.4$ kW (9.4\%)

Peak Pulse Charge Power @, 1 second $^{\mathrm{h}}: 1.3 \mathrm{~kW}(3.7 \%)$

Analysis Notes:

a. Motor refers to any motor capable of supplying traction power

b. Motor power rating refers to the manufacturer's peak power rating for the motor(s) supplying traction power.

c. Vehicle test results are derived from baseline testing of Altima VIN: 2351.

d. The peak power at a specified duration is the average power value over a specified interval beginning at the measured maximum power of the pulse.

e. The capacitylenergy value is defined as the net value over a 1-mile, full-throttle acceleration test.

f. Cumulative capacity measurement over two hot start urban drive cycles and two hot start highway drive cycles.

g. Ratio is calculated as the ratio of measured capacity discharge to measured capacity regenerated. The initial and final states of charge are not specifically

known, but are controlled by the battery management system and are within its normal range.

h. Calculated value based on selected battery voltage limits and at 50\% SOC of measured capacity at the time of testing

i. All values are the degradation or difference in the battery from initial laboratory test to final laboratory test. 